\title{
Comparative dermatology: blue nevus *
}

\author{
Dermatologia comparativa: nevo azul
}

\author{
Jefferson Alfredo de Barros ${ }^{1}$ \\ Juliano Cesar de Barros ${ }^{1}$ \\ Priscila dos Santos Costa ${ }^{2}$
}

\author{
Cristiane Calcidoni Kafler ${ }^{2}$ \\ Rodrigo Sestito Proto ${ }^{3}$ \\ Carlos D'Apparecida Machado Filho ${ }^{4}$
}

\begin{abstract}
There are elements in nature that may be compared to some dermatological lesions, such as the black pearl, which is very similar to a cellular blue nevus observed in the gluteus region of a 31-year-old male patient.

Keywords: Nevus, blue; Skin diseases; Skin neoplasms

Resumo: A natureza pode oferecer elementos passíveis de comparação com algumas lesões dermatológicas, como a semelhança entre a pérola negra e o nevo azul celular observado na região glútea de paciente do sexo masculino, 31 anos.

Palavras-chave: Dermatopatias; Neoplasias cutâneas; Nevo azul
\end{abstract}

Black pearls are the rarest kind of pearl found in nature. They grow in the waters of French Polynesia, where the oysters named Pinctada margaritifera, also known as the black-lipped oysters, are found. A pearl is formed when a strange body (such as a grain of sand) is deposited inside the bivalve of an oyster, between the mantle and the shell, causing an intense inflammatory process. The oyster reacts producing a secretion composed of nacre, which builds up in thin concentric layers that overlap originating "pearlescence" (i.e., a nacreous glow) (Figure 1). ${ }^{1,2}$

In many ways, the black pearl is similar to the lesion found in a 31-year-old male patient, grayish- brown skin, who presented a bluish-brown, clearly defined, rounded, moderately firm, nodular tumor in his gluteus region, measuring $4.5 \mathrm{~cm}$, and compatible with giant cellular blue nevus, confirmed by microscopic examination (Figure 2). We opted for the surgical excision of the lesion.

The blue nevus is a neoplasm composed of melanocytes in the reticular dermis. It can be congenital or acquired. The global rate of affected individual is around 3\%. Microscopically, it is characterized by the presence of long, thin, often corrugated melanocytes, grouped to form irregular bundles predominantly in the upper dermis, parallel to the epi-

\footnotetext{
Received on 13.02.2012.

Approved by the Advisory Board and accepted for publication on 30.03.2012

* Work conducted as a requirement for the discipline of Dermatology, ABC School of Medicine, Santo André - São Paulo (SP), Brazil. Financial support: None.

Conflict of interest: None.

M.Sc. in Health Sciences, ABC School of Medicine (Faculdade de Medicina do ABC) - Teaching Assistant of Dermatology, ABC School of Medicine - Santo André (SP), Brazil.

Physician - Resident in Dermatology, ABC School of Medicine - Santo André (SP), Brazil.

M.Sc. in Health Sciences, ABC School of Medicine - Santo André (SP), Brazil.

Professor and Coordinator of the discipline of Dermatology, ABC School of Medicine - Santo André (SP), Brazil

(C)2012 by Anais Brasileiros de Dermatologia
} 


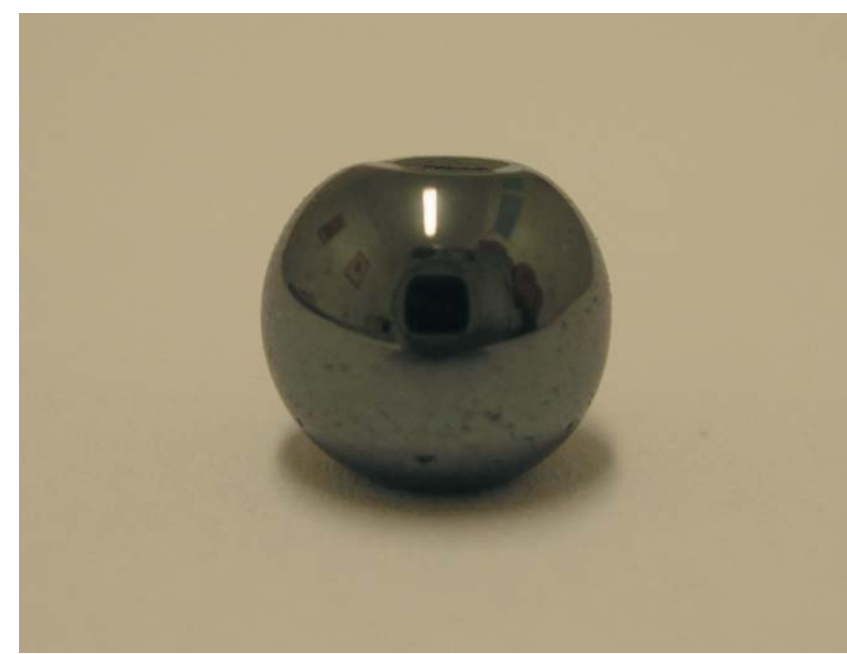

Figure 1: Black pearl

dermis. ${ }^{3}$ It usually affects the skin, though it can also affect other regions such as the uterine cervix, vagina, spermatic cord, oral mucosa, prostate and lymph nodes. ${ }^{4}$ They often come alone. ${ }^{3}$ They can be clinically divided into (i) common - they appear during the first years of life, measuring 2 to $10 \mathrm{~mm}$, found mainly on the limbs and face, and (ii) cellular - measuring more than $10 \mathrm{~mm}$, appearing as firm nodules, mainly

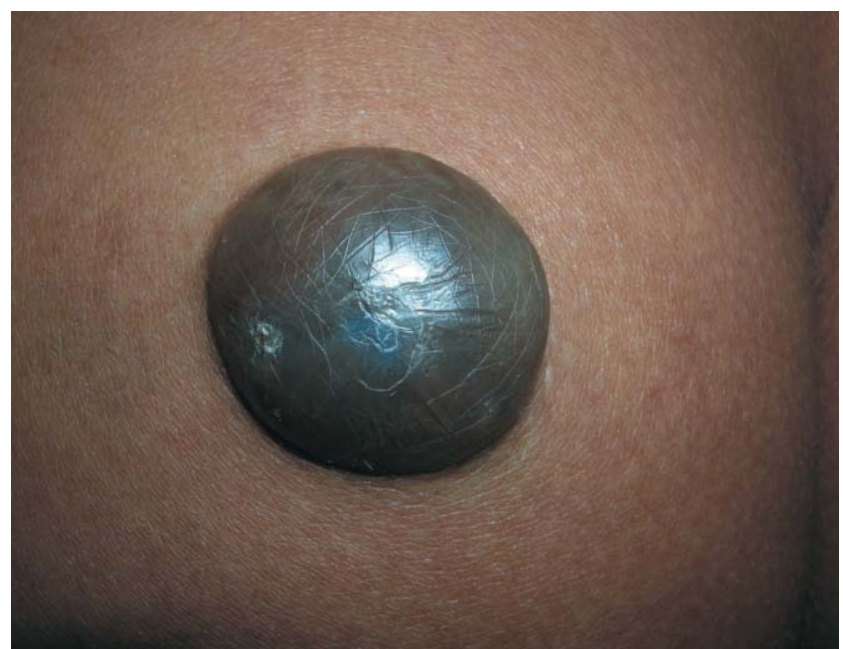

Figure 2: Cellular blue nevus

on the gluteus and sacrococcygeal regions, casually observed at birth, potentially undergoing malignant evolution, with indication for surgical removal 3,4 Some authors describe a third, very rare clinical form, named combined blue nevus, characterized by the overlapping of microscopic aspects of both blue and melanocytic nevus.

\section{REFERENCES}

1. How Stuff Works -A Discovery Company [homepage on the Internet]. "How do oysters make pearls?" [cited 2007 Ago 23]. Available from: http://animals.howstuffworks.com/marine-life/question630.htm

2. Thongnopkun P, Ekgasit S. Characterization of dyed pearls by FT-IR spectroscopy and FT-RAMAN spectroscopy. KMITL Sci J. 2008;8. (Section B, July - December).

3. Murali R, McCarthy SW, Scolyer RA. Blue nevi and related lesions: a review highlighting atypical and newly described variants, distinguishing features and diagnostic pitfalls. Adv Anat Pathol. 2009;16:365-82.

4. Hanna A, Rawal S, Anderson KM, Rawal YB. The epithelioid blue nevus: a rare intraoral nevomelanocytic tumor. J Oral Maxillofac Pathol. 2011:15:88-90.

5. Corrêa LA, Carneiro FR, Meireles VMB, Miranda MFR. Nevo azul combinado gigante: relato de caso. An Bras Dermatol. 1998;73:225-8.
MAILING ADDRESS:

Jefferson Alfredo de Barros

Rua das Figueiras, 1601. Bairro: Campestre

CEP: 09080-371 - Santo André (SP), Brasil

e-mail: jeffersonderma@uol.com.br

How to cite this article: Barros JA, Kafler CC, Barros JC, Proto RS, Costa PS, Machado Filho CD. Comparative dermatology: blue nevus. An Bras Dermatol. 2012;87(4):661-2. 